\title{
Methods for determining water flow from rice field to open drainage system
}

\author{
Dilbar Abduraimova, Makhsud Otakhonov ${ }^{*}$, and Farrukh Babajanov \\ Tashkent Institute of Irrigation and Agricultural Mechanization Engineers, Tashkent, Republic of \\ Uzbekistan
}

\begin{abstract}
Accurate and correct hydraulic calculations are important in the projection of open drainage systems. Because of the hydraulic calculations, it is possible to determine the parameters while constructing it. For calculating the hydraulic, it is necessary to determine the amount of filtration water from the cultivated fields. Crops and irrigation norms differ in the irrigated areas. Of these, rice is the most demanded of water. This article describes how to use GIS to determine the drainage water flow discharge into the open drainage system in the area under cultivation. The research object was the Central Mirzachul open drainage system which was constructed on irrigated land in the south of the Syrdarya region, located in the Mirzachul area. Sentinel 2 satellite imagery was used to identify rice fields in the study area. Downloaded satellite images were analysed using the ArcMap application of ArcGIS, and several steps were taken to create and map a study area. Based on the results of the analysis, the surface and size of the rice fields are determined. Hydraulic calculations were provided based on the determined data. As a result of hydraulic calculations, it was determined that the collector drainage system with the length of $1200 \mathrm{~m}$ drops $4.1 \mathrm{~m} 3 / \mathrm{s}$ water from the rice fields.
\end{abstract}

\section{Introduction}

Collector-drainage systems (CDS) play an important role in improving the reclamation condition of irrigated fields. The main part of the irrigated fields of the Hungry Steppe is made up of sowing areas of the Syr Darya region. To provide water for the irrigated lands of the Syr Darya region in 1896, the Dustlik canal was built [1]. Subsequently, in 1926, 180 $\mathrm{km}$ of canals and canals were built, irrigated areas reached 53 thousand hectares [2]. As a result of the intensive development of the steppes in 1956, irrigated land areas reached 280 thousand hectares, and agricultural products were grown. By constructing in 1960 a canal in the southern Hungry Steppe and Boevut, the Farhad reservoir, the problem of irrigation of the southern part of the Hungry Steppe was solved [3]. The imperfect work of the CDS system led to an increase in the groundwater table, salinization, and worsening of the land reclamation condition. The quality and quantity of agricultural products declined [4]. To improve the reclamation condition of the sowing areas, intensive construction of CDS began. In the beginning, drainage systems Shuruzak, Boevut, and Ettisay were built. Then,

\footnotetext{
*Corresponding author: maqsudxon.otaxonov.87@mail.ru
} 
the drainage systems of Sardoba and Vostochny were built [5]. In 1958, build Central Hunger-Steppe collector with a length of $90 \mathrm{~km}$ began to serve to remove saline water from the Boevut and Ettisay water supply networks [6]. To ensure the intensive operation of drainage systems in the Syr Darya region, they are widely conducting treatment works.

Currently, the total length of the CDS on the irrigated areas of the Syrdarya region is $1,6189.8 \mathrm{~km}$ [7]. From them, $7479.13 \mathrm{~km}$ are open CDS, $8709.87 \mathrm{~km}$ closed system. Every year, 1200-1300 km of open drainages were cleaning. To do this first provides measurements and projecting work in open drainages [8]. One of the most important tasks in projecting is determining the amount of groundwater added to the open CDS [9]. Because of the groundwater flow into the open water systems, creating an uneven mode of water movement. When substantiating the hydraulic parameters of open drainage sections, it is necessary to consider the uneven flow and water discharge regime [10]. At present, the task of groundwater discharge measurement remains one of the most pressing problems. This is because there are a wide variety of agricultural crops planted on open fields [11]. As you know, the regime of irrigation of agricultural crops varies widely. This process affects groundwater. Research has shown that the most demanding water is rice. The rate of irrigation on rice fields is $25,000 \mathrm{~m}^{3} /$ ha during the season [12]. This leads to an increase in the level and discharge of groundwater. As a result, the groundwater added to the open circuit increases water flow and causes an uneven mode of movement. Deterioration of filtration water from rice fields to open streams has been a problem until now [13]. It was necessary to organize a special expedition of 4-5 people and to do field measurements to determine the size of rice fields.

\section{Materials and Methods}

Identification of areas under rice. Studies have been carried out to determine the discharge of filtration water from rice fields. The Central Mirzachul open drainage system in the Syrdarya region was selected as the research object. The total length of the Central Mirzachul open CDS is $84.70 \mathrm{~km}$. Of this, a portion of the area falls on the area where rice is planted. One of the main problems in the research was determining the size of the area under rice. To solve the above problem, GAT technology was used. This is because GIS technology is now widely used in the field of application and penetrates into almost all areas [14-16]. The ability to easily analyze remote sensing data (RS) data at GIS increases the degree of its use in various fields. Another useful feature is using images to explore areas that are difficult to navigate and explore [17-19]. However, initially, they were of low resolution and were not available in the water sector [20-22]. Therefore, there are very few studies using RS in existing computational calculations in the water sector to date. GIS is a satellite analysis of ground changes based on satellite data [23-25]. There are more than 300 satellites in the universe today. But each of them is different in its area of application [26]. Existing satellites differ in their characteristics, such as scope, accuracy, quality, and data speed [27]. Sentinel 2 satellites were selected to study and analyze the above changes.

The MSI measures reflected radiance through the atmosphere within 13 spectral bands. The spatial resolution is dependent on the particular spectral band:

- 4 bands at 10 meters: blue $(490 \mathrm{~nm})$, green $(560 \mathrm{~nm})$, red $(665 \mathrm{~nm})$, and near-infrared $(842 \mathrm{~nm})$.

- 6 bands at 20 meters: 4 narrow bands for vegetation characterization $(705 \mathrm{~nm}, 740 \mathrm{~nm}$, $783 \mathrm{~nm}$, and $865 \mathrm{~nm}$ ) and 2 larger SWIR bands (1,610 nm and 2,190 nm) for applications such as snow/ice/cloud detection or vegetation moisture stress assessment.

- 3 bands at 60 meters: mainly for cloud screening and atmospheric corrections (443 nm for aerosols, $945 \mathrm{~nm}$ for water vapor, and $1375 \mathrm{~nm}$ for cirrus detection). 
Table 1. SENTINEL-2 Radiometric and Spatial Resolutions

\begin{tabular}{|c|c|c|c|}
\hline Band Number & $\begin{array}{c}\text { Central } \\
\text { Wavelength }(\mathrm{nm})\end{array}$ & $\begin{array}{c}\text { Bandwidth } \\
(\mathrm{nm})\end{array}$ & $\begin{array}{c}\text { Spatial } \\
\text { Resolution } \\
(\mathrm{m})\end{array}$ \\
\hline 1 & 443 & 20 & 60 \\
\hline 2 & 490 & 65 & 10 \\
\hline 3 & 560 & 35 & 10 \\
\hline 4 & 665 & 30 & 10 \\
\hline 5 & 705 & 15 & 20 \\
\hline 6 & 740 & 15 & 20 \\
\hline 7 & 783 & 20 & 20 \\
\hline 8 & 842 & 115 & 10 \\
\hline $8 \mathrm{a}$ & 865 & 20 & 20 \\
\hline 9 & 945 & 20 & 60 \\
\hline 10 & 1375 & 30 & 60 \\
\hline 11 & 1610 & 90 & 20 \\
\hline 12 & 2190 & 180 & 20 \\
\hline TCI* & RGB & Composite & 10 \\
\hline
\end{tabular}

The analysis was used the Arc Map tool of ArcGIS software. In the first step, Sentinel 2 Satellite images were downloaded free of charge from GloVis US official website. Although there are several sites where satellite images can be downloaded, their usage status is different. Each site has its own requirements for its use. The Global Visualization Viewer (GloVis) internet application can easily download all US satellite images. The program was launched by USGS. The United States Geological Survey (USGS) was founded on March 3, 1879. USGS is an organization that provides RS data, which is important for monitoring ecosystems and natural health, natural factors, natural resources, climate, and changes in the Earth's surface. USGS collects, monitors, analyzes, and conducts scientific analyzes of changes and problems in the state of natural resources. Downloaded data were analysed and created the map by ArcMap application of ArcGIS software. The size of the rice fields in the research section of the open CDS was determined. Based on the analysis of the results, rice fields were identified.

\section{Results and Discussion}

Open CDS length of the chosen area using ArcMap software was measured. According to the results, the length of the open CDS in the selected section is 1200 meters in length (Figure 1). 


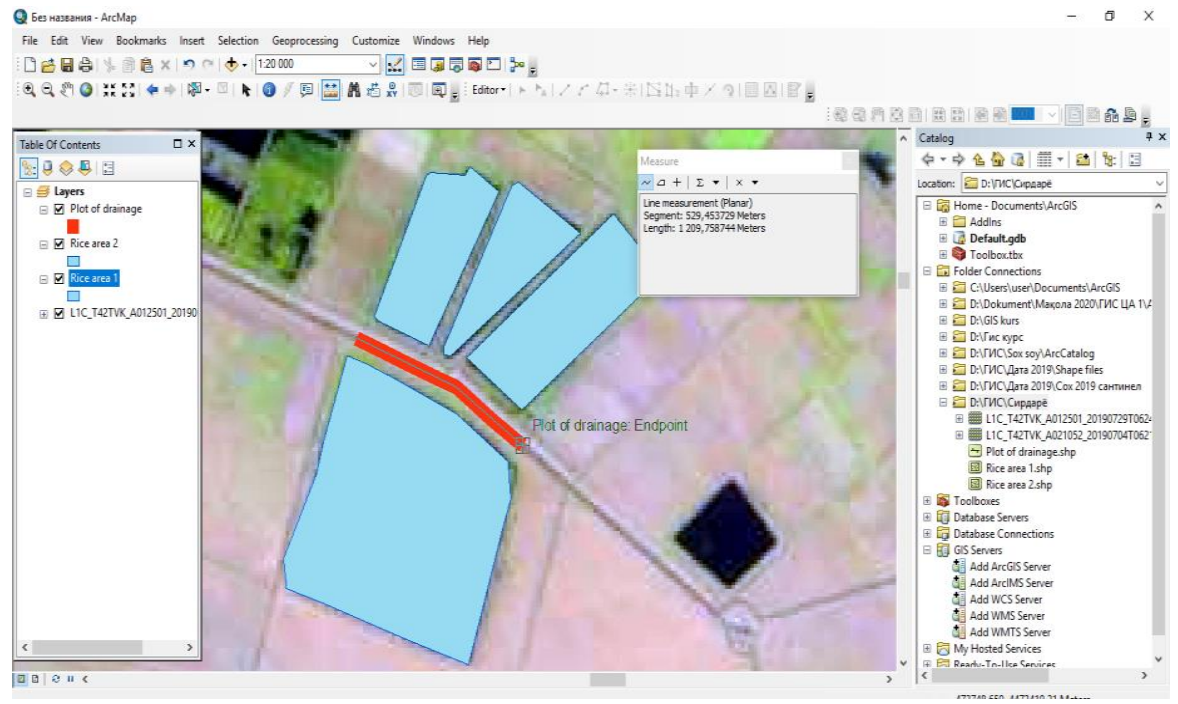

Fig. 1. Determine the length of the open CDS

The next step was measured the surface area of rice fields situated on the right and left sides of the open CDS. As a result of measurements, it was found that the rice fields on the right side of the open drainage were divided into 3 sections. The surface area of the left rice field is 153 ha, with an average length of $1350 \mathrm{~m}$ relative to the bank of the CDS (Figure 2).

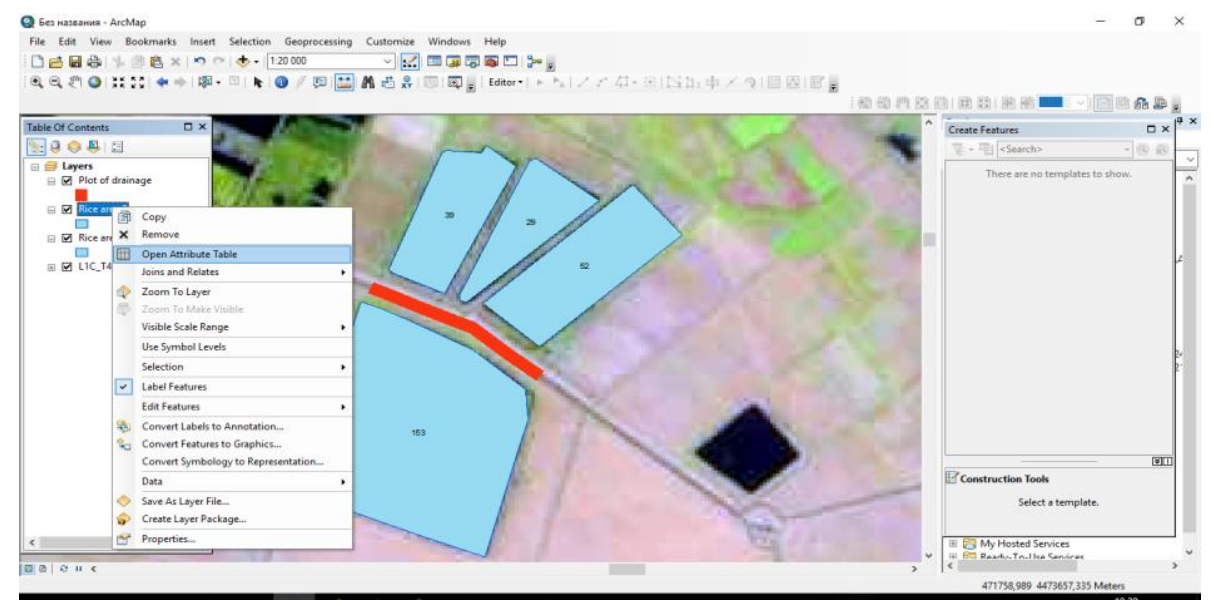

Fig. 2. Determination of the surface area of the rice field

The surface of rice fields was determined based on the data obtained using GIS technology. Based on the data, it was possible to determine the discharge of filtration water from rice fields.

Used the Darsi formula to determine the filtration discharge from rice fields:

$$
q=k_{f} \cdot \frac{H^{2}-h^{2}}{L}
$$


there: $q$ is water flow discharge which adds from one side to $1 \mathrm{~m}$ of area of CDS, $k_{f}$ is filtration coefficient, $H$ is maximum depth of underground water, $h$ is water depth in open CDS, $L$ is length of rice field.

We determine the water consumption along the total length of the open ditch by the following formula.

$$
Q=q \cdot L_{d}
$$

there: $L_{d}$ is length of open CDS.

Calculation analysis is given in Table 2.

Table 2. Determination of water drainage from rice fields

\begin{tabular}{|c|c|c|c|c|c|c|c|c|}
\hline № & Rice field & $\begin{array}{c}\mathrm{k}_{\mathrm{f}}, \\
\mathrm{m}^{2} / \text { day }\end{array}$ & $\mathrm{H}, \mathrm{m}$ & $\mathrm{h}, \mathrm{m}$ & $\mathrm{L}, \mathrm{m}$ & $\mathrm{q}, \mathrm{l} / \mathrm{s}$ & $\mathrm{L}_{\mathrm{d}}, \mathrm{m}$ & $\begin{array}{c}\mathrm{Q}, \\
\mathrm{m}^{3} / \mathrm{s}\end{array}$ \\
\hline 1 & Right side & 0.253 & 3 & 1.1 & 1300 & 1.65 & 1200 & 1.98 \\
\hline 2 & Left side & 0.253 & 3.1 & 1.1 & 1350 & 1.77 & 1200 & 2.12 \\
\hline 3 & $\begin{array}{c}\text { Total } \\
\text { discharge }\end{array}$ & & & & & & & 4.1 \\
\hline
\end{tabular}

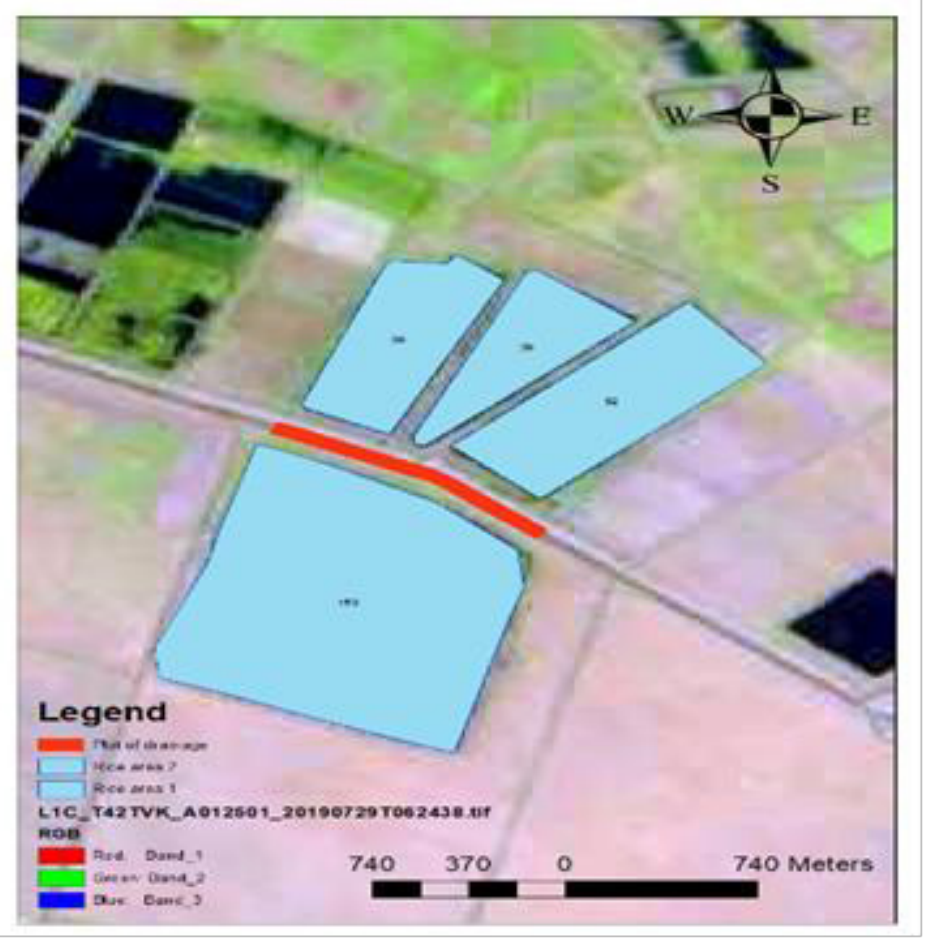

Fig. 3. Map of open CDS and rice field 


\section{Conclusions}

The use of GIS technology gives accurate results in determining the water discharge which required for planning and constructing open CDS. The main effect is that it decreases the time for field measurements and allows for a lot of data analysis in a short period.

Authors thanks to Professor A.M.Arifjanov, Head of the Department of "Hydraulics and Hydroinformatics" of the Tashkent Institute of Irrigation and Agricultural Mechanization Engineers, who provided various advice and assistance in writing this article.

\section{References}

1. Bichsel C. From dry hell to blossoming garden: metaphors and poetry in Soviet irrigation literature on the Hungry Steppe, 1950-1980, Water History, 9(3), pp. 337359, (2017)

2. Matley I.M. The Golodnaya steppe: a Russian irrigation venture in Central Asia, Geographical Review, pp.328-346, (1970)

3. Baymuratova G.T. Mycoflora of Hungry steppe, p. 19, Tashkent (1963).

4. Demina S. Soil Electroconductivity as a Proxy to Monitor the Desertification in the Hungry Steppe (Uzbekistan), Green Technologies and Infrastructure to Enhance Urban Ecosystem Services: Proceedings of the Smart and Sustainable Cities Conference, p. 125, (2019)

5. Vasenev V. Soil Electroconductivity as a Proxy to Monitor the Desertification in the Hungry Steppe (Uzbekistan), Smart and Sustainable Cities Conference, pp. 125-132, Springer, Cham, (2018).

6. Arifzhanov A.M. Distribution of Suspended Sediment Particles in a Steady-State Flow. (2001) Water Resources, 28 (2), pp. 164-166. doi: 10.1023/A:1010375500148

7. Arifjanov A., Samiev L., Ahmedov I. Calculation of bottom sediments in mountain rivers based of field data, Asian Journal of Research, pp.1-3, (2019)

8. Fatkhullaev A, Samiev L. Channel processes and river sediments (Tashkent 2017) p. 132.

9. Karaushev A. Theory and methods of calculation of river sediments, Leningrad, p. 444, (1977)

10. Jawak S.D., and Luis A.J. A Rapid Extraction of Water Body Features from Antarctic Coastal Oasis Using Very High-Resolution Satellite Remote Sensing Data, Aquatic Procedia, 4, pp. 125-32, (2015)

11. Arifzhanov A.M. Method for calculation of the distribution of drift particles in variable section beds (VSB) Gidrotekhnicheskoe Stroitel'stvo, (2), pp. 44-45, (2004)

12. Arifjanov A., Akmalov Sh., Ahmedov I., Atakulov D. Evaluation of deformation procedure in waterbed of rivers, XII International Scientific Conference on Agricultural Machinery Industry, (2019)

13. Jurík L., Zeleňáková M., Kaletová T., Arifjanov A. Small water reservoirs: sources of water for irrigation (2019) Handbook of Environmental Chemistry, 69, pp. 115-131. doi: 10.1007/698_2018_301

14. Arifjanov A.M., A $k$ malov Sh.B., Samiev L.N. Prediction of future water use based on Landsat image analysis in case of Syrdarya Province. Journal of "Sustainable Agriculture" 1(2), p. 6. (2019)

15. Akmalov Sh.B., Blanpain O., Masson E. Study of ecological changes in Syrdarya province by using the Remote Sensing GEOBIA analysis method. Irrigatsiya va melioratsiya jurnali, 8(22), pp.15-19, Tashkent, (2017) 
16. Platt R.V. Wildfire Hazard in the Home Ignition Zone: An Object-Oriented Analysis Integrating LiDAR and VHR Satellite Imagery. Applied Geography, 51. pp. 108-17, (2014)

17. Arifjanov A., Gapparov F., Apakxujaeva T., Xoshimov S. Determination of reduction of useful volume in water reservoirs due to sedimentation, IOP Conference Series: Earth and Environmental Science, 614(1), (2020), doi: 10.1088/17551315/614/1/012079

18. Ronczyk M., Wojtaszek-Levente M. Object-Based Classification of Urban Land Cover Extraction Using High Spatial Resolution Imagery, International Scientific Footprint, Ecological, (2012).

19. Alsubaie N.M. The Potential of Using WorldView-2 Imagery for Shallow Water Depth Mapping. Thèse de doctorat. Université de Calgary. Alberta, p.85. (2012).

20. Arifjanov A., Xodjiyev N., Jurayev S., Kurbanov K., Samiev L. Increasing heat efficiency by changing the section area of the heat transfer pipelines, IOP Conference Series: Materials Science and Engineering, 869(4), (2020), doi: 10.1088/1757899X/869/4/042019

21. Arifjanov A., Rakhimov K., Abduraimova D., Babaev A., Melikuziyev S. Hydrotransport of river sediments in hydroelelators. IOP Conference Series: Materials Science and Engineering, 869(7). (2020), doi: 10.1088/1757-899X/869/7/072003.

22. Arifjanov A., Rakhimov K., Abduraimova D., Akmalov S. Transportation of river sediments in cylindrical pipeline (2019), IOP Conference Series: Earth and Environmental Science, 403(1). DOI: 10.1088/1755-1315/403/1/012154

23. Arifjanov A., Samiev L., Apakhodjaeva T., Akmalov S. Distribution of river sediment in channels, (2019), IOP Conference Series: Earth and Environmental Science, 403 (1). DOI: 10.1088/1755-1315/403/1/012153

24. Arifjanov A., Akmalov S., Akhmedov I., Atakulov, D. Evaluation of deformation procedure in waterbed of rivers, IOP Conference Series: Earth and Environmental Science, 403 (1), (2019), DOI: 10.1088/1755-1315/403/1/012155

25. Arifjanov A., Apakhodjaeva T., Akmalov S. Calculation of losses for transpiration in water reservoirs with using new computer technologies, International Conference on Information Science and Communications Technologies: Applications, Trends and Opportunities, (2019), DOI: 10.1109/ICISCT47635.2019.9011883

26. Arifjanov A., Samiev L., Akmalov S. Dependence of fractional structure of river sediments on chemical composition.) International Journal of Innovative Technology and Exploring Engineering, 9(1), pp. 2646-2649, (2019, DOI: 10.35940/ijitee.L2944.119119

27. Arifjanov A., Otaxonov M., Samiev L., Akmalov S. Hydraulic calculation of horizontal open drainages (2019) E3S Web of Conferences, 97. DOI: $10.1051 / \mathrm{e} 3$ sconf/20199705039 